\title{
HUBUNGAN POLA MAKAN TERHADAP STATUS GIZI PASIEN RAWAT JALAN DIABETES MELITUS TIPE 2 DI WILAYAH KERJA RUMAH SAKIT GRANDMED LUBUK PAKAM
}

\author{
Raini Panjaitan ${ }^{1}$, Reno Irwanto ${ }^{2}$, Andreais Boffil Cholilullah ${ }^{3}$, Salmi Angraini ${ }^{4}$ \\ Program Studi Gizi Fakultas Kesehatan Masyarakat \\ Institut Kesehatan Medistra Lubuk Pakam \\ Jl. Sudirman No. 38 Lubuk Pakam Kec. Lubuk Pakam Kab. Deli Serdang, \\ Sumatera Utara \\ e-mail : raini0938p@gmail.com
}

\begin{abstract}
Diabetes mellitus is a chronic disease characterized by hyperlycemia. Risk factors for type 2 diabetes mellitus due to intake of carbohydrates, fats and protein. This study aims to see the relationship between diet in the nutrient status of type 2 diabetes mellitus in out patient in Grandmed Hospital Lubuk Pakam. This research method is an observational description with crosssectional design. The sample is patients type 2 diabetes mellitus in out patient in Grandmed Hospital Lubuk Pakam. The sample is 30 people. The instruments are Food Recall 24 Hours and analyzed by nutrition app Nutri Survey. The data analysis used in this study was the Chi-Square test (95\% CI) From the result of this research showed that $44,6 \%$ of patients with excess carbohydrate intake with a $p$ value of $0.000 \leq a(0,05)$. this research showed that $49,0 \%$ of patients with excess fat intake with a $p$ value of $0.000 \leq a(0,05)$. this research showed that $38,0 \%$ of patients with excess protein intake with a $p$ value of $0.000 \leq a$ $(0,05)$. The conclusion are that there is significant relationship between diet in the nutrient status of type 2 diabetes mellitus in out patient in Grandmed Hospital Lubuk Pakam and type 2 diabetes mellitus in out patient nutrient status characteristics categorized as obesity.
\end{abstract}

Keywords: diet, type ii diabetes mellitus, nutrient status

\section{PEndahuluan}

Penyakit diabetes melitus atau dikenal juga "the mother of disease" salah satu penyakit kronis yang ditandai hiperglikemia kronik dengan gangguan metabolisme zat gizi makro yang berkaitan dengan kelainan sekresi inulin (Febrianti dkk, 2020). Menurut (WHO, 2013) bahwa prevelensi diabetes melitus tipe 2 semakin meningkat yaitu
$90 \%$ dari kasus diabetes melitus di dunia. Di Indonesia data prevelensi diabetes melitus sebesar $6,9 \%$ dan kejadian di provinsi Sumatera Utara sebanyak 160 ribu jiwa atau 1,8 \% (Riskesdas, 2013). Penyakit ini sangat erat dengan asupan makanan seperti karbohidrat, protein dan lemak yang dikonsumsi secara berlebihan. Hal ini yang merupakan faktor resiko kejadian diabetes melitus tipe 2 . 
Penderita diabetes melitus tipe 2 cenderung memiliki status gizi obesitas yang memiliki kadar glukosa darah lebih tinggi yaitu $307 \pm 107,38 \mathrm{mg} / \mathrm{dL}$ dibandingkan yang memiliki status gizi normal yaitu $275,55 \pm 73,79 \mathrm{mg} / \mathrm{dL}$ (Sanal dkk, 2011). Pengendalian glukosa darah diperlukan untuk mencegah komplikasi. Pengendalian glukosa darah dan status gizi dapat dilakukan dengan memperhatikan perilaku pola makan. Berdasarkan hasil observasi yang dilakukan di Rumah Sakit Grandmed Lubuk Pakam bahwa diperoleh data sebanyak 22 pasien rawat jalan penderita diabetes tipe 2 dengan status gizi obesitas. Oleh sebab itu perlu dilakukan penelitian hubungan pola makan penderita diabetes terhadap status gizi.

\section{METODE PENELITIAN}

Jenis penelitian yang digunakan pada penelitian ini adalah survei analitik, dengan desain penelitian yaitu cross sectional menggunakan populasi penelitian adalah pasien rawat jalan penderita diabetes tipe 2 di Rumah Sakit Grandmed Lubuk Pakam. Teknik pengambilan sampel yang digunakan dalam penelitian ini adalah teknik simple random sampling yang berjumlah 45 orang. Analisis data yang dilakukan

Tabel 2. Hubungan Asupan Karbohidrat terhadap Status Gizi Pasien Rawat Jalan Penderita Diabetes Tipe 2

\begin{tabular}{|c|c|c|c|c|c|c|c|c|c|}
\hline \multirow{3}{*}{$\begin{array}{l}\text { Asupan } \\
\text { Karbohidrat }\end{array}$} & \multicolumn{6}{|c|}{ Status Gizi } & \multirow{2}{*}{\multicolumn{2}{|c|}{ Total }} & \multirow{3}{*}{ P Value } \\
\hline & \multicolumn{2}{|c|}{ Kurang } & \multicolumn{2}{|c|}{ Normal } & \multicolumn{2}{|c|}{ Lebih } & & & \\
\hline & $\mathbf{n}$ & $\%$ & $\mathbf{n}$ & $\%$ & $n$ & $\%$ & $\mathbf{n}$ & $\%$ & \\
\hline Kurang & 4 & 8,9 & 2 & 4,4 & 4 & 8,9 & 10 & 22,2 & \\
\hline Cukup & 1 & 2,2 & 3 & 6,7 & 8 & 17,7 & 12 & 26,6 & 0,000 \\
\hline Lebih & 1 & 2,2 & 2 & 4,4 & 20 & 44,6 & 23 & 51,2 & \\
\hline Total & 6 & 13,3 & 7 & 15,5 & 32 & 71,2 & 45 & 100 & \\
\hline \begin{tabular}{cc}
\multicolumn{2}{c}{ Tabel } \\
antara $\quad$ asup
\end{tabular} & 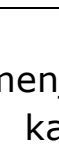 & skan & & & $\begin{array}{l}\text { diab } \\
\text { diuk } \\
\text { kem }\end{array}$ & $\begin{array}{l}\text { tip } \\
\text { dens } \\
\text { ian }\end{array}$ & & supar & $\begin{array}{ll}\text { karbohi } \\
\text { call } 24 \\
\text { an apl }\end{array}$ \\
\hline
\end{tabular}

yaitu analisis univariat dan analisis bivariat.

\section{HASIL}

Tabel 1. Distribusi Karakteristik Responden

\begin{tabular}{llcc}
\hline No & Karakteristik & $\mathbf{f}$ & $\mathbf{\%}$ \\
\hline 1 & Usia & & \\
& $\leq 45$ & 15 & 33,4 \\
& $\geq 46$ & 30 & 66,6 \\
\hline \multirow{2}{*}{$\begin{array}{l}\text { Total } \\
2\end{array}$} & Pendidikan & $\mathbf{4 5}$ & $\mathbf{1 0 0 , 0}$ \\
& SD & & \\
& SMP & 8 & 17,7 \\
& SMA & 12 & 26,6 \\
& PT & 19 & 42,2 \\
& & 6 & 13,5 \\
& Total & 4 & \\
\hline 3 & Status Gizi & $\mathbf{4 5}$ & $\mathbf{1 0 0 , 0}$ \\
& Kurang & $\mathbf{6}$ & $\mathbf{1 3 , 3}$ \\
& Normal & $\mathbf{7}$ & $\mathbf{1 5 , 5}$ \\
& Lebih & $\mathbf{3 2}$ & $\mathbf{7 1 , 2}$ \\
\hline & Total & $\mathbf{4 5}$ & $\mathbf{1 0 0 , 0}$ \\
\hline
\end{tabular}

Tabel 1 menunjukkan bahwa dari 45 orang penderita diabetes tipe 2 dapat diketahui bahwa sebagian besar kelompok yang berusia $\geq 45$ tahun ada $66,6 \%$, memiliki pendidikan SMA ada $42,2 \%$ dan memiliki status gizi lebih atau obesitas sebesar $71,2 \%$. 
penelitian bahwa responden dengan status gizi lebih atau obesitas memiliki asupan karbohidrat yang lebih sebesar $44,6 \%$.

Tabel 3. Hubungan Asupan Lemak terhadap Status Gizi Pasien Rawat Jalan Penderita Diabetes Tipe 2

\begin{tabular}{|c|c|c|c|c|c|c|c|c|c|}
\hline \multirow{3}{*}{$\begin{array}{l}\text { Asupan } \\
\text { Lemak }\end{array}$} & \multicolumn{6}{|c|}{ Status Gizi } & \multirow{2}{*}{\multicolumn{2}{|c|}{ Total }} & \multirow{3}{*}{ P Value } \\
\hline & \multicolumn{2}{|c|}{ Kurang } & \multicolumn{2}{|c|}{ Normal } & \multicolumn{2}{|c|}{ Lebih } & & & \\
\hline & $\mathbf{n}$ & $\%$ & $\mathbf{n}$ & $\%$ & $\mathbf{n}$ & $\%$ & $n$ & $\%$ & \\
\hline Kurang & 3 & 6,7 & 1 & 2,2 & 3 & 6,7 & 7 & 15,6 & \\
\hline Cukup & 2 & 4,4 & 4 & 8,9 & 7 & 15,5 & 13 & 33,2 & 0,000 \\
\hline Lebih & 1 & 2,2 & 2 & 4,4 & 22 & 49,0 & 23 & 51,2 & \\
\hline Total & 6 & 13,3 & 7 & 15,5 & 32 & 71,2 & 45 & 100 & \\
\hline
\end{tabular}

bahwa $49,0 \%$ responden penderita

Tabel 4. Hubungan Asupan Protein terhadap Status Gizi Pasien Rawat Jalan Penderita Diabetes Tipe 2

\begin{tabular}{|c|c|c|c|c|c|c|c|c|c|}
\hline \multirow{3}{*}{$\begin{array}{l}\text { Asupan } \\
\text { Protein }\end{array}$} & \multicolumn{6}{|c|}{ Status Gizi } & \multirow{2}{*}{\multicolumn{2}{|c|}{ Total }} & \multirow{3}{*}{ P Value } \\
\hline & \multicolumn{2}{|c|}{ Kurang } & \multicolumn{2}{|c|}{ Normal } & \multicolumn{2}{|c|}{ Lebih } & & & \\
\hline & $\mathbf{n}$ & $\%$ & $\mathbf{n}$ & $\%$ & $n$ & $\%$ & $n$ & $\%$ & \\
\hline Kurang & 3 & 6,7 & 4 & 8,9 & 7 & 15,5 & 14 & 31,1 & \\
\hline Cukup & 2 & 4,4 & 1 & 2,2 & 8 & 17,7 & 11 & 24,3 & 0,000 \\
\hline Lebih & 1 & 2,2 & 2 & 4,4 & 17 & 38,0 & 20 & 44,6 & \\
\hline Total & 6 & 13,3 & 7 & 15,5 & 32 & 71,2 & 45 & 100 & \\
\hline
\end{tabular}

Tabel 4. menjelaskan hubungan antara asupan protein dengan status gizi responden. Tabel di atas menunjukkan bahwa $38 \%$ responden penderita diabetes tipe 2 memiliki status gizi lebih dengan asupan konsumsi protein yang berlebih juga dengan hasil uji statistik diperoleh $p=0,000$.

\section{PEMbahasan}

Berdasarkan hasil analisis yang diperoleh dengan uji chi square menunjukkan nilai $p$ value $(0,000) \leq a$ $(0,05)$. Hal menggambarkan adanya hubungan asupan karbohidrat terhadap status gizi penderita diabetes tipe 2 di wilayah kerja Rumah Sakit Grandmed asupan karbohidrat menunjukkan status gizi lebih atau obesitas (Tabel 2). Oleh karena itu, variabel asupan karbohidrat merupakan faktor status gizi lebih. Menurut (Werdani dan Triyanti, 2014) bahwa jumlah asupan karbohidrat yang berlebih dapat memicu terjadinya obesitas dan resistensi insulin. Pada saat proses pencernaan karbohidrat maka karbohidrat akan dipecah menjadi gula sederhana/glukosa yang kemudian akan diserap oleh usus halus dan masuk ke saluran peredaran darah. Semakin tinggi jumlah asupan karbohidrat maka jumlah kadar gula di dalam darah semakin tinggi. 
Pada Tabel 3. berdasarkan hasil analisis diperoleh dengan uji chi square menunjukkan nilai $p$ value $(0,000) \leq a$ $(0,05)$. Hal ini menunjukkan hubungan asupan lemak antara status gizi penderita diabetes tipe 2 . Bahwa semakin tinggi asupan lemak maka status gizi berlebih. Semakin tinggi asupan lemak maka dapat memicu meningkatnya jumlah lemak dalam tubuh mengakibatkan terjadinya obesitas atau kegemukan. Asupan lemak yang berlebih mampu meningkatkan kadar gula darah (Werdani dan Triyanti, 2014).

Berdasarkan hasil penelitian diketahui bahwa asupan protein memiliki hubungan dengan status gizi nilai $p$ value $(0,000) \leq a(0,05)$. Asupan protein yang berlebih dapat mengakibatkan obesitas dan dapat mempengaruhi kadar gula darah. Protein memiliki fungsi sebagai sumber energi melalui proses glukoneogenesis (Muliani, 2013)

\section{KESIMPULAN}

Berdasarkan hasil penelitian maka diperoleh kesimpulan bahwa terdapat hubungan yang signifikan antara asupan karbohidrat, lemak dan protein terhadap status gizi penderita diabetes melitus tipe 2 nilai $p$ value $(0,000) \leq a(0,05)$. Karakteristik pola makan pasien rawat jalan penderita diabetes tipe 2 menunjukkan asupan karbohidrat, lemak dan protein dengan kategori berlebih dan status gizi obesitas/berlebih.

\section{DAFTAR PUSTAKA}

Febrianti D., Thaha MR., Hidayanty H. (2020). POLA MAKAN PASIEN RAWAT JALAN DM TIPE 2 DI RUMAH SAKIT PENDIDIKAN UNHAS. JKMM, 3(1), 45-56.
Muliani U. (2013). ASUPAN ZAT-ZAT GIZI DAN KADAR GULA DARAH PENDERITA DM-TIPE2 DI POLIKLINIK PENYAKIT DALAM RSUD Dr. H. ABDUL MOELOEK PROVINSI LAMPUNG. JURNAL KESEHATAN, 4(2), 325-332.

Riset Kesehatan Dasar (Riskesdas). (2013). Laporan Nasional 2013. Jakarta: Badan Penelitian dan Pengembangan Kesehatan Depkes RI.

Sanal TS., Nair NS., Adhikari P. (2011).Factors Associated with poor control of type 2 diabetes melitus systematic review and meta-analysis. Journal Diabetology, 3(1), 1-10.

Werdani RA., Triyanti. (2014). ASUPAN KARBOHIDRAT SEBAGAI FAKTOR DOMINAN YANG BERHUBUNGAN DENGAN KADAR GULA DARAH PUASA. JURNAL KESEHATAN MASYARAKAT NASIONAL, 9(1), 7177.

World Health Organization (WHO). (2013). Diabetes Mellitus. https://www.who.int/mediacenter/ factsheets/fs312/en/ 